\title{
A Guide to Nesting Sea Turtles in Florida ${ }^{1}$
}

\section{Analisa Duran, Ruth Frances-Floyd, Maia Patterson Mcguire, and Iskande Larkin²}

\section{Objective}

The purpose of this document is to provide an overview of nesting sea turtles in the state of Florida along with information on nesting characteristics, life histories, species identification, and distribution for loggerhead, green and leatherback turtles.

\section{Overview of Sea Turtles} \section{Types of Sea Turtles Nesting in Florida}

There are seven species of sea turtles, which fall into two families. Six species are in the family Cheloniidae, or hard-shelled sea turtles:

- loggerhead, Caretta caretta

- green, Chelonia mydas

- hawksbill, Eretmochelys imbricata

- Kemp's ridley, Lepidochelys kempii

- olive ridley, Lepidochelys olivacea

- flatback, Natator depressus

The flatback turtle is found only in Australia. The other five species of hard-shelled sea turtles do occur in Florida waters, but only the loggerhead and green turtles routinely nest on Florida beaches.

The second family of sea turtle is the Dermochelydae, or soft-shelled sea turtles. The leatherback sea turtle
(Dermochelys coriacea) is the only living species in this family. This species is found in Florida waters, and females nest on Florida beaches.

Florida's coastline provides critical nesting habitat for three species of sea turtles, the loggerhead, green, and the leatherback. Hawksbill turtles nested on Florida beaches in the past but are not currently consistent nesters in the state. Kemp's ridley turtles are found nesting mainly in Rancho Nuevo on Mexico's Gulf coast. They can also be found sparsely nesting on Florida and south Texas beaches. In 2018, there were a total of 12 Kemp's ridley nests in the entire state of Florida.

\section{Sea Turtle Life History}

Sea turtles have been using beaches as nesting grounds since the early Pliocene, a time of global cooling that took place about 5.3 to 2.6 million years ago. This was long before humans began developing coastlines. Although there are two families of sea turtles, their basic life history strategies are similar.

1. Females mate at near-shore sites and have the ability to store sperm for weeks at a time.

2. They crawl onto beaches to dig a nest in the sand and deposit their eggs. Mothers then leave the nest, providing no parental care.

1. This document is FA235, one of a series of the School of Forest, Fisheries, and Geomatics Sciences, UF/IFAS Extension. Original publication date June 2021. Visit the EDIS website at https://edis.ifas.ufl.edu for the currently supported version of this publication.

2. Analisa Duran, graduate student, School of Forest, Fisheries, and Geomatics Sciences; Ruth Frances-Floyd, professor and UF/IFAS Extension veterinarian, College of Veterinary Medicine and School of Forest, Fisheries, and Geomatics Sciences; Maia Patterson Mcguire, UF/IFAS Florida Sea Grant agent IV, St. Johns and Flagler Counties, Bunnell, Florida 32110; and Iskande Larkin, lecturer, education coordinator, and interim director, Aquatic Animal Health, University of Florida College of Veterinary Medicine; UF/IFAS Extension, Gainesville, FL 32611.

The Institute of Food and Agricultural Sciences (IFAS) is an Equal Opportunity Institution authorized to provide research, educational information and other services

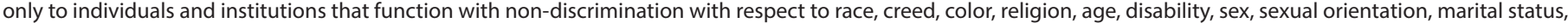

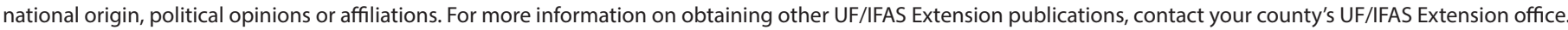
U.S. Department of Agriculture, UF/IFAS Extension Service, University of Florida, IFAS, Florida A \& M University Cooperative Extension Program, and Boards of County Commissioners Cooperating. Nick T. Place, dean for UF/IFAS Extension. 
3. After about two months, baby sea turtles hatch and emerge from their nests, usually at night. The hatchlings crawl quickly to the brightest horizon, which in a natural environment, is the reflection of moonlight on the surf.

4. Once they reach the water, hatchlings go into a "swimming frenzy," swimming out to sea where they drift in ocean currents and take cover in floating sargassum (a type of seaweed). During this time, sea turtles feed on small plankton and/or fish that are also finding refuge in the floating seaweed habitat. This life stage can also be called the pelagic stage, in which sea turtles are referred to as juveniles. This can last from 10-12 years.

5. The next stage in a sea turtle's life is called sub-adult/ adult. During this phase, they join coastal populations at feeding grounds. When a sea turtle is sexually mature, (anywhere from 20-30 years old) it will embark on a breeding migration. This migration will lead turtles to where they were born, their natal region, to breed and nest.

\section{Sea Turtle Lifespan}

The natural life span of sea turtles is estimated to be between 50 and 100 years. Because sea turtles spend a large portion of their lives in the pelagic (open) ocean, it is very difficult to study them. Most information we have on sea turtles comes from nesting turtles, since they are the most accessible and cost-efficient to study as they come onshore.

\section{How to Identify Sea Turtle Species}

Species can be identified in a few ways (see Figures 1 and 2):

\section{By the number of scutes on their carapace}

\section{By the prefrontal scales between their eyes}

\section{By the coloration of their carapace}

Depending on the species, a sea turtle can have 4-5 costal scutes (see next paragraph) on each side of their carapace and 1-2 prefrontal scales in between their eyes (Figures 1 and 2). The coloration of a sea turtle's carapace can be brown, green/olive, orange, or black. Throughout this publication, species characteristics are listed within their respective section.

The shell on the sea turtle's back is called a carapace. Each individual scale on the shell is called a scute. The scute directly behind the head of the sea turtle is called the nuchal scute. Following this begins a row of vertebral scutes, which are located in a line down the middle of the sea turtle's back. Moving outward from the vertebral scutes are the costal scutes. Finally, the outermost scutes are called the marginal scutes (Figure 2). Learning to recognize the scutes is important when trying to identify a turtle species.

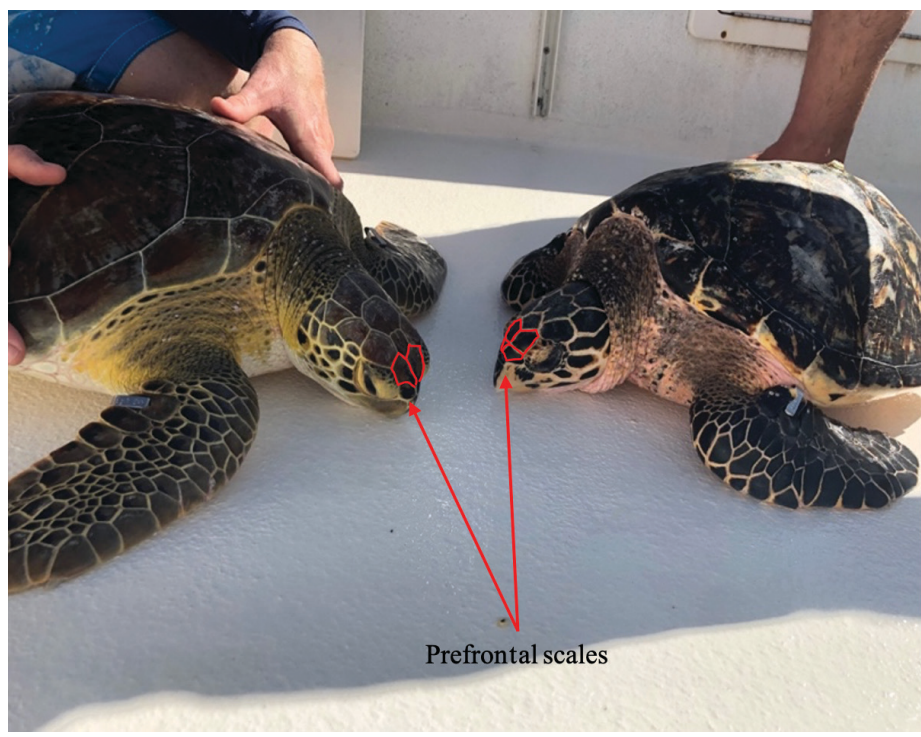

Figure 1. Green turtle (left) and hawksbill turtle (right). Green turtle: one pair of prefrontal scales; hawksbill turtle: two pairs of prefrontal scales.

Credits: Analisa Duran, UF/IFAS

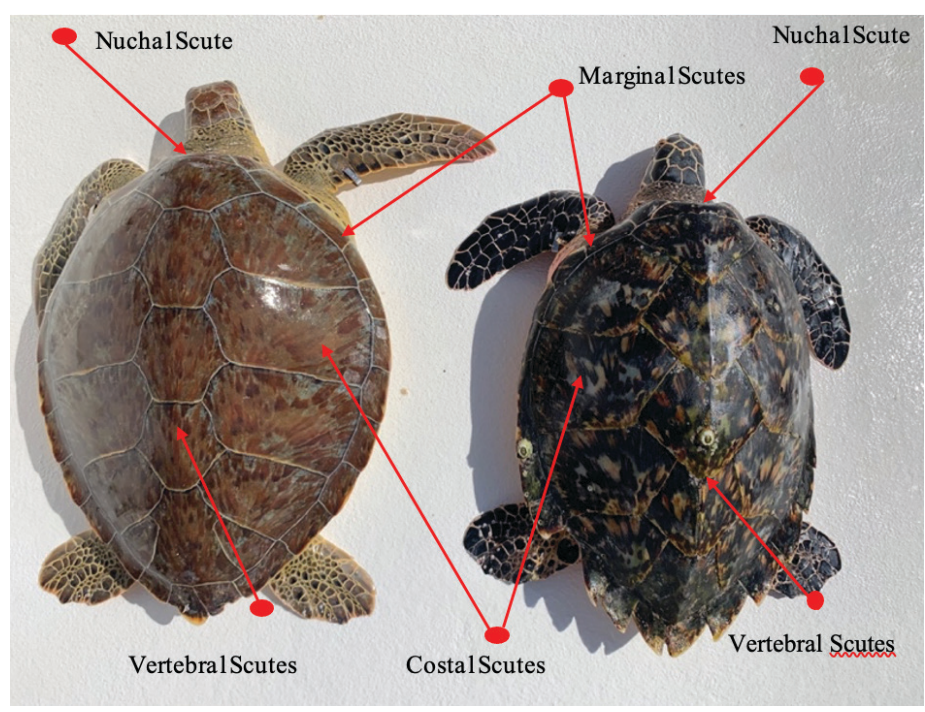

Figure 2. Green turtle (left) and hawksbill turtle (right). Costal, marginal and vertebral scutes listed.

Credits: Analisa Duran, UF/IFAS

In addition to the carapace and scutes, there are scales on the head and body of the sea turtle. Prefrontal scales, which are the scales between the eyes of the sea turtle, are used to identify species (Figure 1).

Generally, a sea turtle can be identified by looking at the morphology of the scutes and prefrontal scales. Although species hybrids may occur, they are rare. A hybrid turtle may have odd variations of specific scutes, making identification difficult. 
What does it mean when you see measurements of sea turtles?

These measurements are taken in two ways by scientists who study turtles.

1. Straight carapace length is the length of the turtle's carapace measured by researchers with calipers (Figure $3)$.

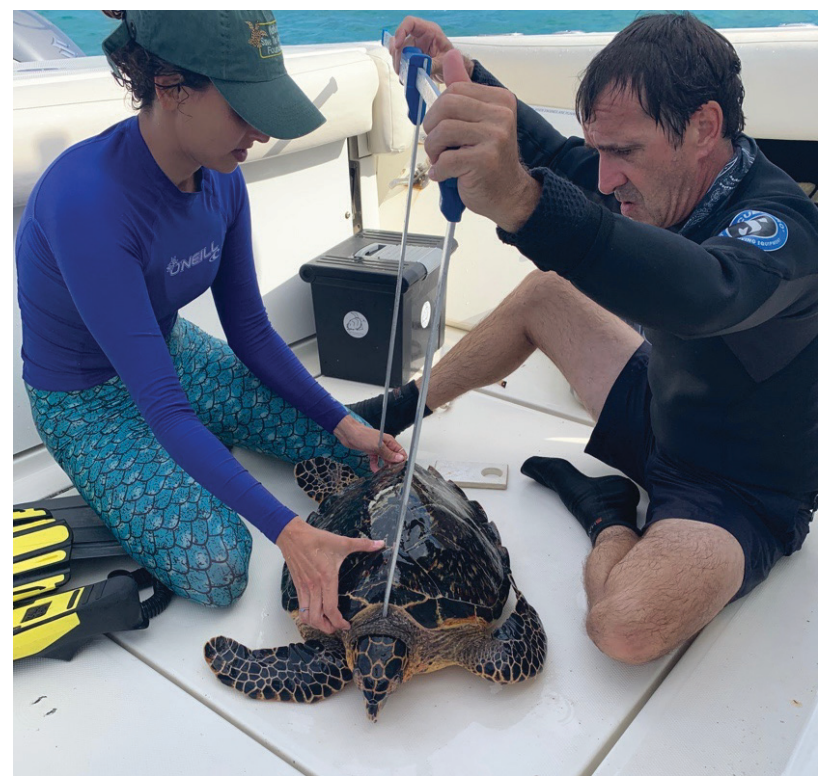

Figure 3. Biologists from National Save the Sea Turtle Foundation collecting the straight carapace length of a hawksbill sea turtle. Credits: Analisa Duran, UF/IFAS

2. Curved carapace length is the length of a turtle's carapace measured with measuring tape in order to take into account the curvature of the carapace.

Sea turtle species vary in size. When reading through this publication, please note that the sizes of sea turtle species are measured as straight carapace length.

\section{Florida's Nesting Sea Turtles Loggerhead turtle, Caretta caretta WHERE DO LOGGERHEAD TURTLES NEST?}

Loggerhead turtles (Figure 4) are the most common sea turtles that nest on Florida's beaches.

Florida: Southern Florida is one of only two nesting assemblages in the world in which there are 10,000 or more female loggerhead individuals nesting each year. (Witherington, et al. 2006). 80\% of loggerhead nests in Florida are reported from six counties in the southeastern part of the state (Figure 5): Brevard, Indian River, St. Lucie, Martin, Palm Beach, and Broward. While loggerheads nest on other beaches throughout the data, these beaches have high densities of nests.
United States: Loggerhead turtles can be found nesting from southern (east and west coast) Florida to North Carolina.

Worldwide: Spain, Africa, Australia, Bahamas, México, Brazil, Greece, Japan, and more.

Nesting Beaches: Loggerheads prefer to nest mid beach between the high tide line and the dune. Loggerhead nests can be found on narrow, grainy beaches with a slope.

\section{Nesting Months (Florida):May through October}

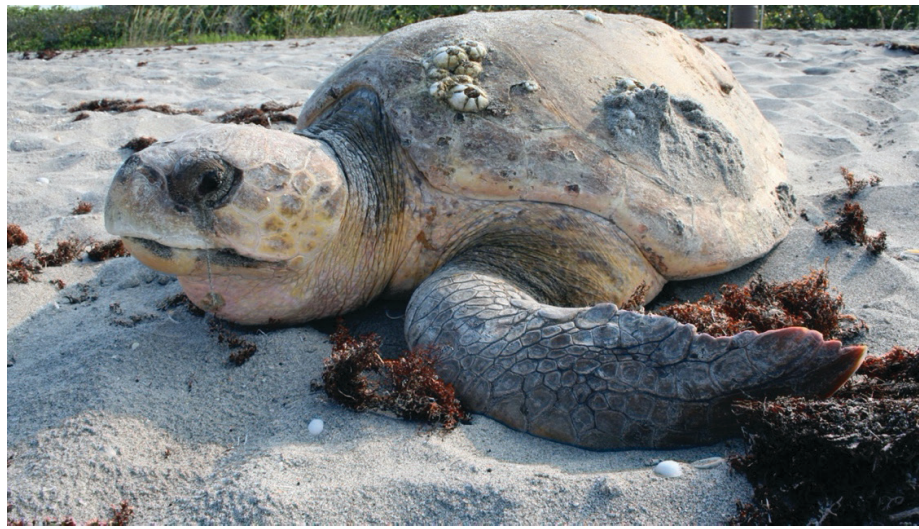

Figure 4. Loggerhead sea turtle.

Credits: Lawrence Wood, Founder and Director of the Comprehensive Florida Hawksbill Research and Conservation Program

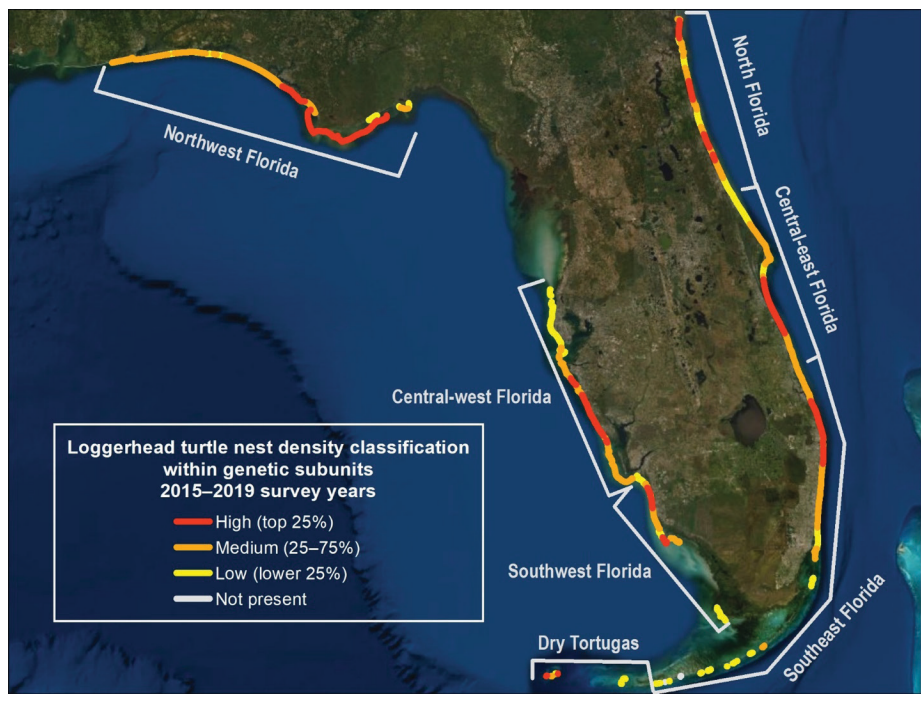

Figure 5. Loggerhead nest density (measured in number of nests per kilometer of beach) by genetic subunit in Florida during a recent fiveyear period (2015-2019). High-density beaches are those having the top 25 percent of density values (red); low-density beaches have the lowest 25 percent (yellow); and beaches with densities between these two categories are defined as medium-density beaches (orange).

White indicates beaches where loggerhead turtles were not observed to have nested during the five-year period. The white brackets indicate the genetic subunits.

Credits: FWC/FWRI Statewide Atlas of Sea Turtle Nesting Occurrence and Density as of 20 February 2020. https://myfwc.com/research/ wildlife/sea-turtles/nesting/nesting-atlas 


\section{LOGGERHEAD IDENTIFICATION}

Size: $35-39$ in $(90-100 \mathrm{~cm})$

Defining characteristics: Large orange heads, brown shell or carapace, two pairs of prefrontal scales between their eyes, non-overlapping carapace scutes, and five pairs of costal scutes.

\section{LOGGERHEAD CONSERVATION STATUS}

US Endangered Species Act: Threatened

\section{QUICK FACTS ABOUT LOGGERHEAD TURTLE NESTS}

- Loggerhead nests are 10-20 in. $(25-50 \mathrm{~cm})$ deep and 20 in. $(51 \mathrm{~cm})$ in diameter

- Females have been known to travel across oceans to breed every 1-9 years; a 2 to 4 -year interval between reproductive cycles is most common.

- Florida female loggerheads will lay approximately four nests per nesting season.

- It will take a mother loggerhead about one hour and 35 minutes to lay her eggs.

- Each loggerhead turtle nest has an average of 116 eggs per nest.

- Baby turtles hatch and emerge from the nest 49-58 days after the nest is laid.

\section{WHAT DOES A LOGGERHEAD TURTLE CRAWL LOOK LIKE?}

Adult female loggerhead turtles crawl on the beach with an alternating limb movement. This results in a unique "track" characterized by diagonal flipper marks in the sand, reflecting the alternating limb movements (Figure 6). Loggerhead turtles leave no "tail-drag" mark down the center of their crawl (Figure 7). Loggerhead crawls have an average width of $37 \mathrm{in}$. $(95 \mathrm{~cm})$. It is important to note that injuries to a flipper on the turtle can modify crawl characteristics.

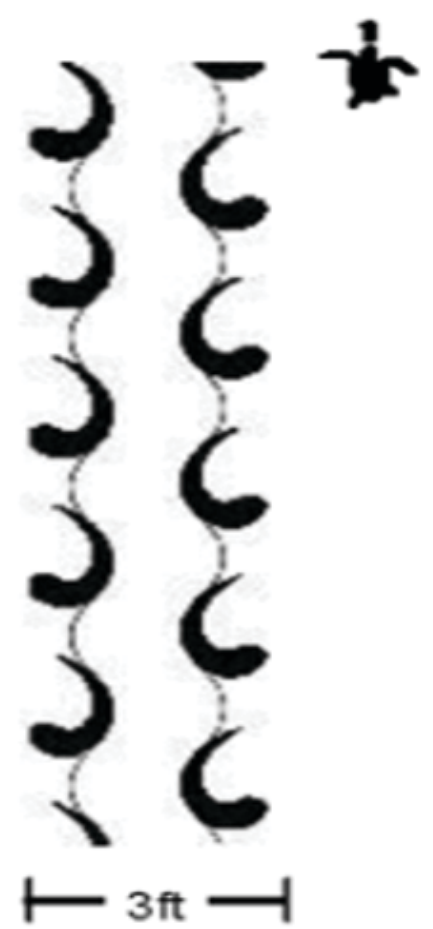

Figure 6. Loggerhead sea turtle crawl.

Credits: Dawn Witherington, Drawn by Dawn

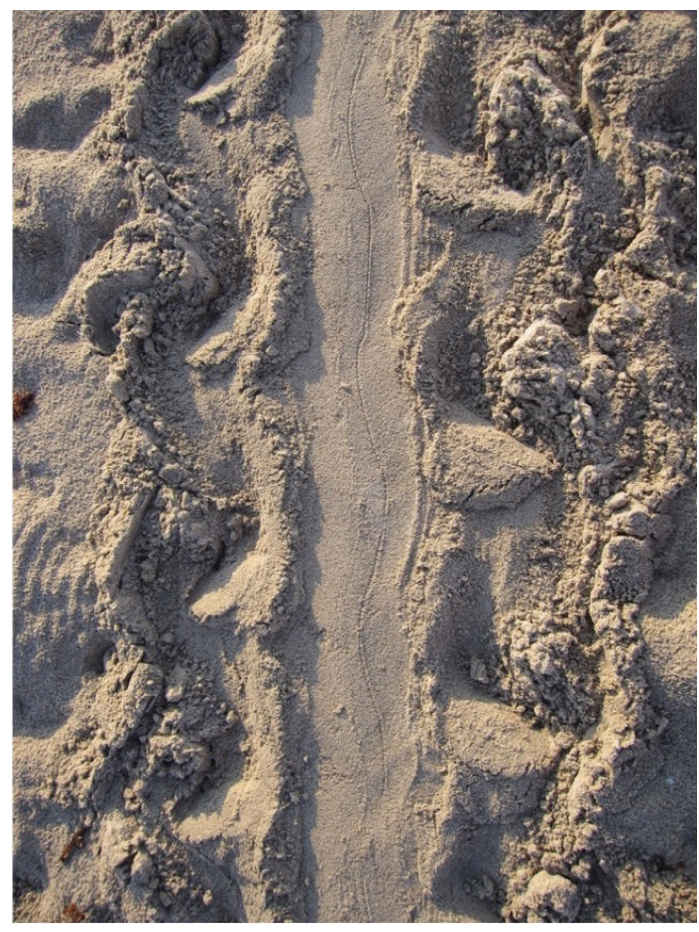

Figure 7. Loggerhead sea turtle crawl.

Credits: Lawrence Wood, Founder and Director of the Comprehensive Florida Hawksbill Research and Conservation Program

\section{Green Turtle, Chelonia mydas WHERE DO GREEN TURTLES NEST?}

The green turtle (Figure 8) is the second most abundant nesting sea turtle along Florida's coastline).

Florida: Florida is second or third in the annual number of green turtle nests laid on beaches on the western Atlantic. 
Almost every coastal county in Florida has recorded green turtle nesting, but approximately $99 \%$ of the green turtle nesting in Florida occurs on the Atlantic coast (figure 9) because the density of green turtles in these areas is very high.

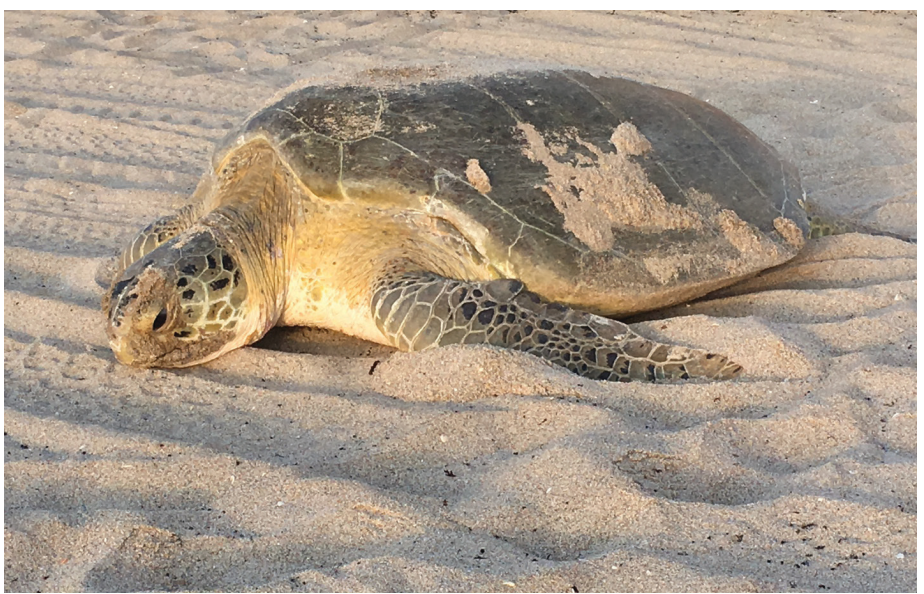

Figure 8. Green sea turtle.

Credits: Lawrence Wood, Founder and Director of the Comprehensive Florida Hawksbill Research and Conservation Program

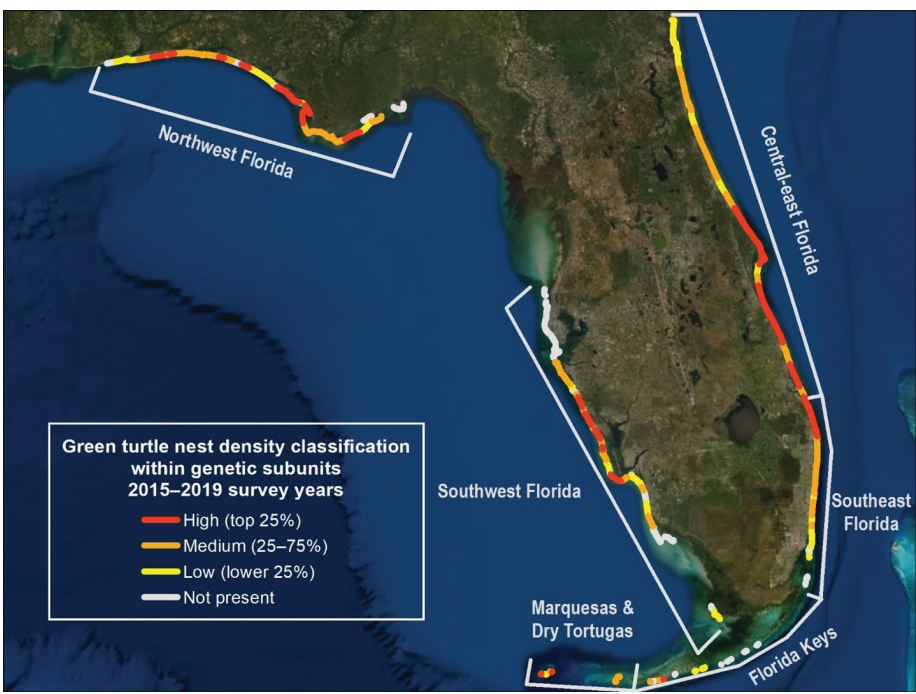

Figure 9. Green turtle nest density (measured in number of nests per kilometer of beach) by genetic subunit in Florida during a recent fiveyear period (2015-2019). High-density beaches are those having the top 25 percent of density values (red); low-density beaches have the lowest 25 percent (yellow); and beaches with densities between these two categories are defined as medium-density beaches (orange). White indicates beaches where green turtles were not observed to have nested during the five-year period. The white brackets indicate the genetic subunits.

Credits: FWC/FWRI Statewide Atlas of Sea Turtle Nesting Occurrence and Density as of 20 February 2020.

Worldwide: Costa Rica, Indonesia, Australia, Hawaii, and more.

Nesting Beaches: Green sea turtles prefer barrier island beaches. These are beaches that receive high wave energy and have coarse sand, steep slopes, and prominent foredunes. Green turtles typically lay their nests near the base of the primary dune.

Nesting Months (Florida): June through September

\section{GREEN TURTLE IDENTIFICATION}

Size: $36-48$ in. $(91-121 \mathrm{~cm})$

Defining Characteristics: Oval head shape, a single pair of large prefrontal scales (refer to Figures 1 and 2), a serrated lower jaw, non-overlapping carapace scutes, and four pairs of costal scutes. Although their shells have a green/ olive/brown color, they received their name because of the greenish color of their fat.

\section{GREEN TURTLE CONSERVATION STATUS}

US Endangered Species Act: Threatened.

\section{QUICK FACTS ABOUT GREEN TURTLE NESTS}

- It is hypothesized that female green turtles remigrate to Florida every two years, which matches a clear biennial pattern of high and low nesting years.

- Throughout all green turtle populations around the world, remigration intervals range from 2 to 5 years.

- Female green turtles in Florida lay an average of 3.6 nests per season.

- The nesting process for a green turtle takes about two hours.

- Florida green turtle clutch size averages 136 eggs.

- Incubation time for green turtle nests in Florida averages 52-56 days.

\section{WHAT DOES A GREEN TURTLE CRAWL LOOK LIKE?}

Adult female green turtles crawl on the beach with a simultaneous limb movement that results in slashes from the front flippers at the margins of the track and creates parallel flipper marks (Figure 10). They have a straight and thin tail-drag mark down the center of their crawl (Figure 11). A green sea turtle crawl is approximately 47 inches $(120 \mathrm{~cm})$ wide. As with the loggerhead sea turtle, injuries to a flipper can alter crawl characteristics. 

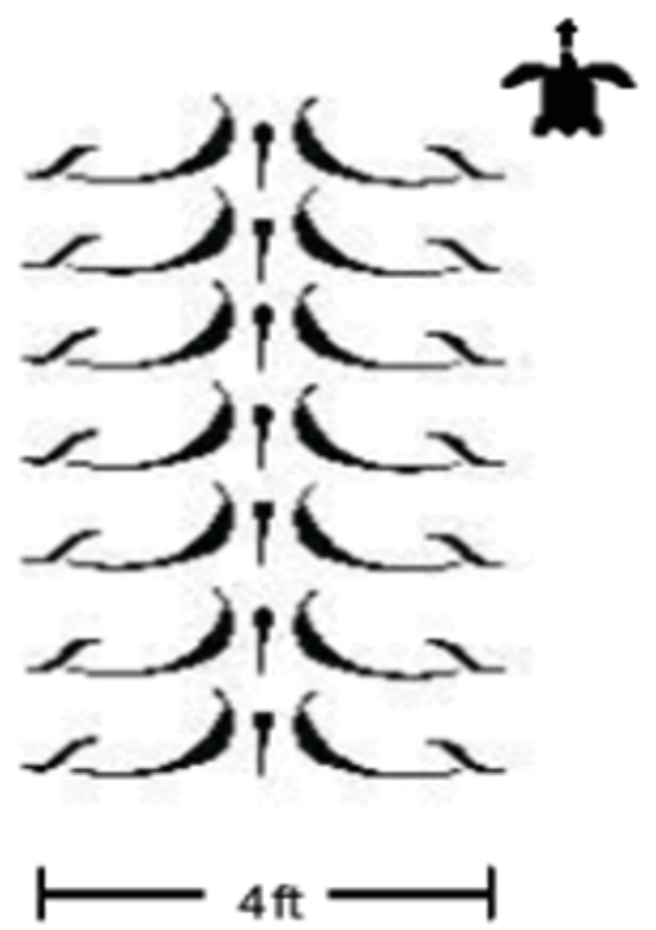

Figure 10. Green sea turtle crawl.

Credits: Dawn Witherington, Drawn by Dawn

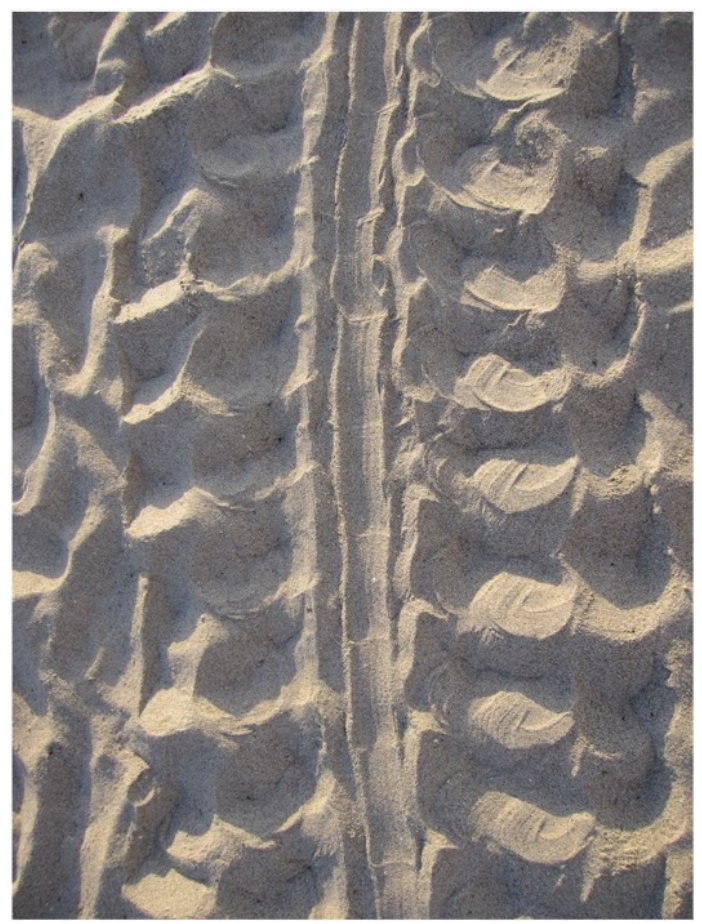

Figure 11. Green sea turtle crawl.

Credits: Lawrence Wood, Founder and Director of the Comprehensive Florida Hawksbill Research and Conservation Program

\section{Leatherback turtles, Dermochelys coriacea WHERE DO LEATHERBACK TURTLES NEST?}

Leatherback turtles (Figure 12) are the most widely distributed reptile in the world.

Florida: For the past decade, leatherbacks have laid an average of 508 nests per year, with most nesting activity occurring along the Atlantic coast from Brevard to Broward counties, but they occur in most counties on Florida's east coast and have been reported along the Panhandle (Figure 13). While leatherbacks have been nesting in Florida for centuries, the first recorded leatherback nest was in 1947.

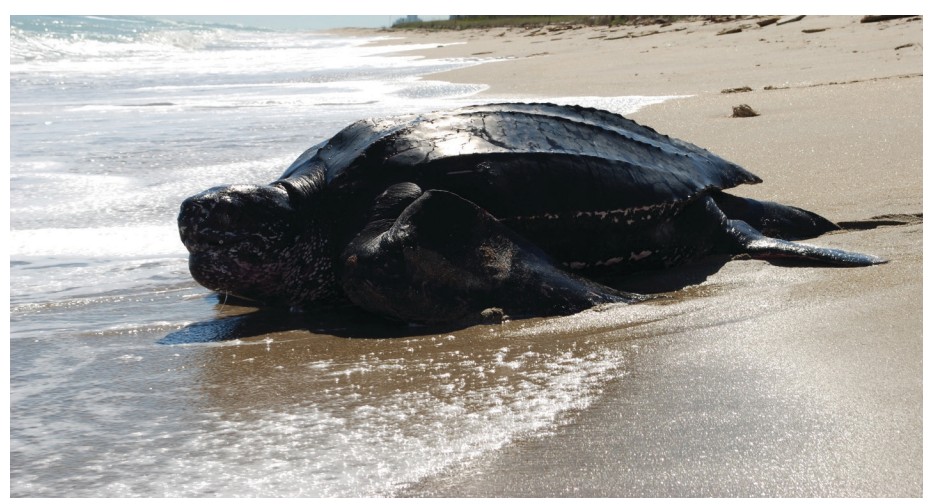

Figure 12. Leatherback sea turtle.

Credits: Lawrence Wood, Lawrence Wood, Founder and Director of the Comprehensive Florida Hawksbill Research and Conservation Program

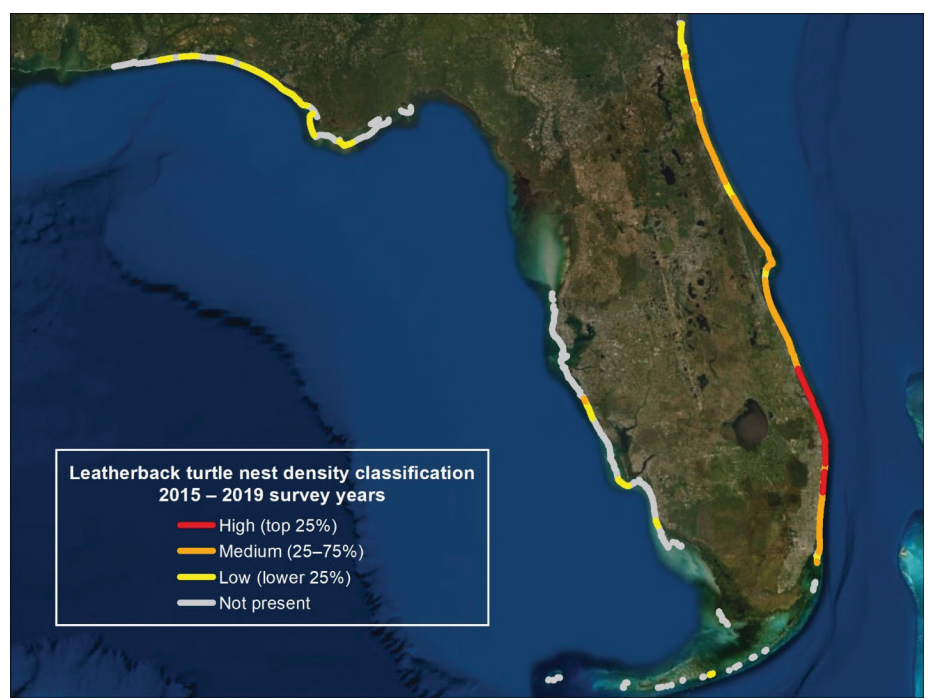

Figure 13. Leatherback nest density (measured in number of nests per kilometer of beach) in Florida during a recent five-year period (20152019). High-density beaches are those having the top 25 percent of density values (red); low-density beaches have the lowest 25 percent (yellow); and beaches with densities between these two categories are defined as medium-density beaches (orange). White indicates beaches where leatherbacks were not observed to have nested during the five-year period.

Credits: FWRI Statewide Atlas of Sea Turtle Nesting Occurrence and Density as of 20 February 2020.

United States: Nests have occasionally been reported in Georgia, South Carolina, and as far north as North Carolina.

Worldwide: Leatherback turtles are found in the Pacific, Atlantic, and Indian Oceans. Eastern and western Pacific leatherback turtles nest in tropical latitudes around the world. 
Nesting Beaches: A sandy beach with dune vegetation that is sloped sufficiently so the distance to dry sand is minimal. Leatherback nesting beaches usually have proximity to deep water and generally rough seas.

Nesting Months (Florida): March through May

\section{LEATHERBACK TURTLE IDENTIFICATION}

Size: $54-66$ in. $(137-167 \mathrm{~cm})$

Defining Characteristics: It is not difficult to differentiate leatherback turtles from other species. The carapace is predominately black with white patches on the head and flippers. Leatherback turtles have seven longitudinal ridges along their carapace, and the "shell" is made of fibrous fatty tissue. Their front flippers are almost as long as their bodies, proportionally longer than any other sea turtle species.

\section{LEATHERBACK TURTLE CONSERVATION STATUS}

US Endangered Species Act: Endangered

\section{QUICK FACTS ABOUT LEATHERBACK TURTLE NESTS}

- The eggs of a leatherback turtle are the largest among turtle species.

- It is common for a leatherback nest to contain spacers, or non-fertile (yolkless) eggs. It is not clear what purpose they serve, if any.

- Leatherback turtles lay 2-6 nests per season.

- The average clutch size for Florida leatherbacks is approximately 73 yolked eggs and 25 spacers.

- For south Florida nests, hatchlings will emerge from the nest approximately 66 days after the nest is laid.

\section{WHAT DOES A LEATHERBACK TURTLE CRAWL LOOK LIKE?}

Adult female leatherback turtle crawls can be distinguished from other species based on their enormous size, simultaneous limb movement that creates parallel flipper marks in the sand, and distinctive tail drag (Figures 14 and 15). Track width is approximately $45 \mathrm{in}$. $(114.3 \mathrm{~cm})$ or more. As with other sea turtle species, injuries to a flipper on the turtle can alter crawl characteristics.

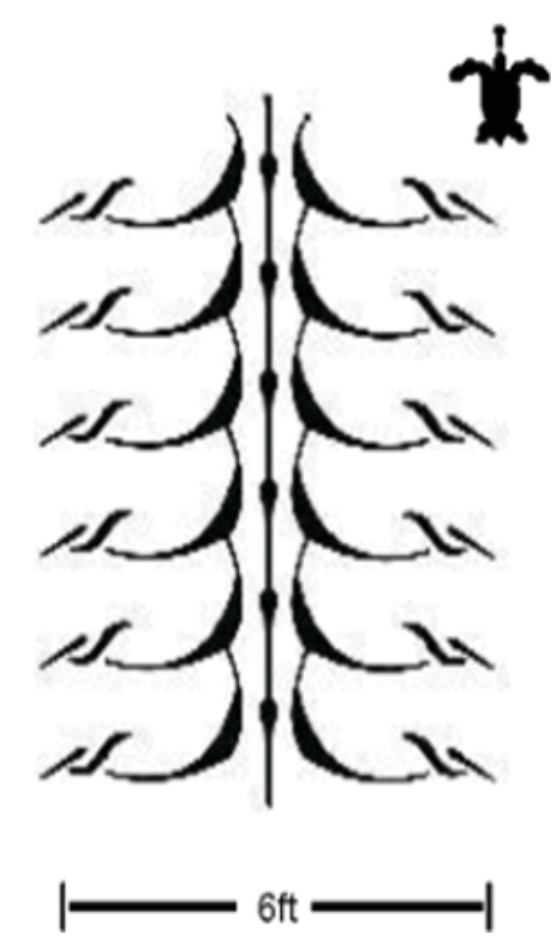

Figure 14. Crawl of a leatherback sea turtle.

Credits: Dawn Witherington, Drawn by Dawn

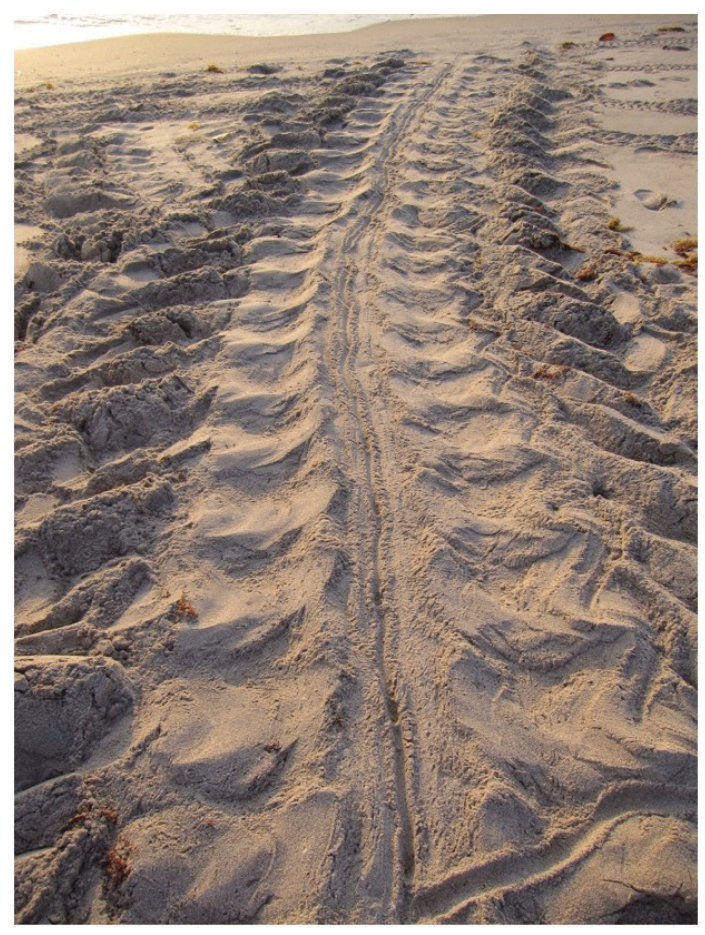

Figure 15. Crawl of a leatherback sea turtle.

Credits: Lawrence Wood, Founder and Director of the Comprehensive Florida Hawksbill Research and Conservation Program

\section{What You Can Do}

During sea turtle nesting seasons, biologists survey beaches for sea turtle activity. They can identify a species by crawl characteristics and can identify if a nest is laid by the appearance of a mound in the sand. In most counties, when a nest is found it is taped off so that beach goers know not to disturb these areas (Figure 16). Some areas have nest 
densities that are so high, surveyors do not mark every nest. Because sea turtle species are protected by the Endangered Species Act, it is unlawful to touch or tamper with sea turtles or their nests.

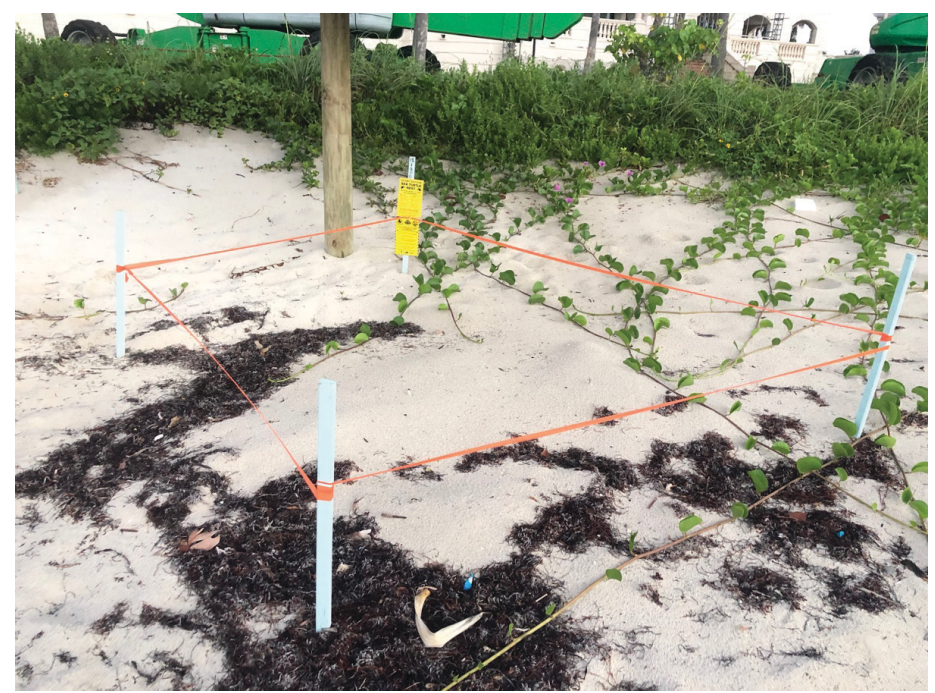

Figure 16. Loggerhead sea turtle nest in Florida.

Credits: Analisa Duran

When on the beach in Florida from May through October, it is important to be mindful of these roped-off nests. Here are a few things you can do to help protect nesting sea turtles in Florida:

1. If you dig a hole in the sand, cover it up before you leave. If the hole is big enough, nesting mothers could fall in on their way into/out of the water. Hatchlings could also fall in holes in the sand on their way to the ocean. Sandcastles can also act as obstacles for nesting turtles or hatchlings.

2. If you live on the beach or are staying at a hotel on the beach, turn off your lights. Sea turtles can become disoriented by bright lights. If your lights are off, the hatchlings can find the ocean much more easily.

3. If you happen to come across hatchling turtles, someone tampering with a sea turtle nest, or a sick, stranded, or dead sea turtle, you should call 1-888-404-3922.

If you are interested in learning more about sea turtle conservation, refer to Sea Turtle Conservation: 10 Ways You Can Help

\section{Summary of Nesting Sea Turtles in Florida}

Florida's entire coastline provides critical habitat for sea turtle nesting, as it has for millions of years. Throughout the state, three of the seven species of sea turtles in the world have significant nesting populations. Loggerhead, green, and leatherback sea turtles use Florida's beaches to lay nests each year. Hawksbills, Kemp's ridley and olive ridley turtles have been sighted off of Florida's coast, but do not regularly nest on Florida beaches.

\section{More Information}

Florida Fish and Wildlife. 2020. Sea Turtle Nesting. https://myfwc.com/research/wildlife/sea-turtles/nesting/

National Oceanic and Atmospheric Administration (NOAA) Fisheries. 2020. Sea Turtle Species.

https://www.fisheries.noaa.gov/sea-turtles

US Fish and Wildlife Service. 2019. General Sea Turtle Information. https://www.fws.gov/northflorida/SeaTurtles/ seaturtle-info.htm

Witherington, B., Herran, R., And Bressette, M. 2006. Caretta Caretta - Loggerhead Sea Turtle. Biology and Conservation of Florida Turtles.

Wood, Lawrence. 2004. A Field Guide for Sea Turtle Nesting Surveys. http://dnr.sc.gov/seaturtle/volres/Wood $\% 20$ Nesting $\% 20$ Field\%20Guide.pdf 